\title{
Integrating Alternative Medicine into Conventional Biomedical Health: How Do We Weight the Evidence
}

\author{
Hana Al-Bannay* \\ New York University Abu Dhabi, UAE \\ Submission: February 23, 2017; Published: September 26, 2017 \\ *Corresponding author: Hana Al-Bannay, New York University Abu Dhabi, P0 Box 129188, Abu Dhabi, United Arab Emirates, \\ Email: hana.albannay@gmaill.com
}

\section{Opinion}

The historical shift towards a scientific revolution after the eighteenth century in Europe has discarded societal and cultural folklore from its dictionary of knowledge. The Oxford Dictionary defines science as "the intellectual and practical activity encompassing the systematic study of the structure and behavior of the physical and natural world through observation and experiment" (2017). The operationalization of scientific thought has placed cultural practices and traditions at the forefront of skepticism [1]. The objectivity of scientific machine has vacated inherited knowledge and beliefs from its missionary to the provision of verified knowledge [2]. Reality, if cannot be tested, will get folded into irrationality along with speculations on the existence of unseen God [3].

Conventional Medicine is among the vast accomplishments of scientific inquiry. The success of biomedical investigation has relied heavily on technological advancement. A tangible evidence of its eminence lies in its credibility to retesting and verifying. The remedial wisdom of forerunning world civilizations on the other hand has become a resort to the less educated, traditional, and God believer [4,5]. The late success of complementary therapies in public credibility is owed in part to the confirmatory voice of scientific testing. Only recently, the Aboriginal communities have attained an acknowledgement by scientific investors for the selling of tree oil tea [6]. The Chinese medicine is suddenly becoming of a significant interest to learn from and integrate into the biomedical perspective [7]. The Japanese Tai Chi is gradually combined to the list of invaluable mental and physical exercises [8]. Despite these achievements, the anthropological school of health is yet to be scrutinized under the lenses of Conventional Medicine.

Interestingly enough, the roots of Conventional Medicine date back to Eastern medicine in Greece and the Arabia [9].
Despite the advancement of contemporary health care by dedicated scholars in the West, the roots of Conventional Medicine remain picked out from their origin and surrounding civilizations. Anthropologists bargaining their credibility through observations in real-world fields are yet disqualified from the rationalism of obsolete objectivity [10]. The integration of Alternative Medicine into Conventional Medicine for the delivery of holistic health stay under the monopoly of biomedical industry.

Complementary therapies, even when not verified by biomedical health, are largely used by individuals in some communities. People in cultures with a wealth of inherited knowledge on traditional medicine are intact to their cultural beliefs about the efficacy of their historical medicinal treatments [11]. Moreover, some people view their cultural healing strategies are more safe and with less if not minimum side effects compared to drugs prescribed by Conventional Medicine [12]. Other cultures view Alternative Medicine less costly and more affordable than Conventional Medicine, especially for the poor and disadvantaged [5].The power of cultural influence turns the voice of scientific objectivity a dispensable need in people realities [12].

Up to date dialogue between anthropologists and biomedical health scholars have not traversed the boundaries for the creation of intersected, balanced perspective [13]. The loss of optimal health has increased under the seeds of disconnecting scientific evidence from cultural traditions of healing. Interprofessional communication between biomedical scholars and health anthropologists requires better efficacy. Future studies to investigate communication channels for the increase of collaborating perspectives and incorporating Alternative Medicine into Conventional Medicine are being warranted. 


\section{References}

1. Novella S (2016) Why Skepticism? Skeptical Inquirer 40(5): 40-43.

2. Gimbel E (2016) Interpretation and objectivity: [12]. Political Research Quarterly 69(1): 72-82.

3. González RF (2016) Advancing the topics of social reality, culture, and subjectivity from a cultural-historical standpoint: moments, paths, and contradictions. Journal of Theoretical and Philosophical Psychology 36(3): 175-189.

4. Boateng MA, Danso-Appiah A, Turkson BK, Tersbøl BP (2016) Integrating biomedical and herbal medicine in Ghana-experiences from the Kumasi south hospital: a qualitative study. BMC Complement Altern Med 16: 189.

5. Kim HJ, Chun KH, Kim DJ, Han SJ, Kim YS, et al. (2011) Utilization patterns and cost of complementary and alternative medicine compared to conventional medicine in patients with type 2 diabetes mellitus. Diabetes Res Clin Pract 93(1): 115-122.

6. Chin KB, Cordell B (2013) The effect of tea tree oil (Melaleucaalternifolia) on wound healing using a dressing model. Journal of Alternative \& Complementary Medicine 19(12): 942-945.

7. Chen YL, Hou MC, Lin SC, Tung YJ (2015) Educational efficacy of objective structured clinical examination on clinical training of traditional Chinese medicine-A qualitative study. Complement Ther Clin Pract 21(3): 147-153.

This work is licensed under Creative

DOI: 10.19080/GJAA.2017.01.555575
8. Nomura T, Nagano K, Takato J, Ueki S, Matsuzaki Y, et al. (2011) The development of a Tai Chi exercise regimen for the prevention of conditions requiring long-term care in Japan. Arch Gerontol Geriatr 52(3): e198-e203.

9. Bhikha R, Glynn J (2017) The role of Tibb in integrative medicine for diseases of lifestyle. Bangladesh Journal of Medical Science 16(1): 1320.

10. Ståhl T, Zaal MP, Skitka LJ (2016) Moralized rationality: relying on logic and evidence in the formation and evaluation of belief can be seen as a moral issue. Plos One 11(11): e0166332.

11. Pérard M, Mittring N, Schweiger D, Kummer C, Witt CM (2015) MERGING conventional and complementary medicine in a clinic department - a theoretical model and practical recommendations. BMC Complement Altern Med 15: 172.

12. Mukolo A, Cooil B, Victor B (2015) The effects of utility evaluations, biomedical knowledge and modernization on intention to exclusively use biomedical health facilities among rural households in Mozambique. Soc Sci Med 138: 225-233.

13. Nichol J, Thompson EA, Shaw A (2011) Beliefs, decision-making, and dialogue about complementary and alternative medicine (CAM) within families using CAM: a qualitative study. J Altern Complement Med 17(2): 117-125.

\section{Your next submission with Juniper Publishers will reach you the below assets}

- Quality Editorial service

- Swift Peer Review

- Reprints availability

- E-prints Service

- Manuscript Podcast for convenient understanding

- Global attainment for your research

- Manuscript accessibility in different formats

( Pdf, E-pub, Full Text, Audio)

- Unceasing customer service

Track the below URL for one-step submission https://juniperpublishers.com/online-submission.php 